\title{
15 CARA SEDERHANA UNTUK MENJALANI HIDUP YANG BAHAGIA
}

\author{
Lavinia Pintox \\ Universitas Kebahagiaan \\ Lavinia@yahoo.com
}

\begin{abstract}
"Kebahagiaan adalah arti dan tujuan hidup, seluruh tujuan dan akhir eksistensi manusia."
\end{abstract}

Aristoteles mengatakan ini lebih dari 2.000 tahun yang lalu. Dan itu masih berlaku hari ini. Apa tujuan hidup yang sebenarnya, jika tidak hidup bahagia sampai kita mati?

Kebahagiaan adalah salah satu tujuan yang paling dicari dalam hidup, tetapi bagi banyak orang tampaknya sulit dipahami. Sangat mudah untuk menipu diri sendiri dengan berpikir, "Ketika saya memiliki rumah yang bagus dan mobil baru, maka saya bisa bahagia." Namun kenyataannya, kebahagiaan tersedia bagi kita semua, saat ini. Rumah besar atau mobil baru tidak akan membuat Anda lebih bahagia; itu adalah sukacita sederhana dalam hidup yang membawa kebahagiaan sejati. Baca terus untuk mempelajari 15 cara sederhana agar Anda dapat mulai menjalani kehidupan yang lebih bahagia saat ini.

\section{Lakukan Apa yang Anda Cintai}

Jika gairah Anda adalah bermain sepak bola, menulis puisi, atau mengajar anak-anak cara berenang, luangkan waktu untuk melakukannya. Anda akan menemukan bahwa ketika Anda melakukan apa yang Anda sukai, Anda dipenuhi dengan sukacita. Seberapa jauh lebih baik daripada memaksakan diri melakukan sesuatu yang tidak Anda sukai?

\section{Bantu Orang Lain}

Kadang-kadang setelah kami mencapai tujuan pribadi kami sendiri, kami masih merasa kosong di dalam karena kami belum memberikan kontribusi yang berarti bagi kehidupan orang lain. Ketika kita menjadi sukarelawan atau membantu orang lain, rasanya menyenangkan hanya melayani orang lain. Dampak yang kami buat terasa memuaskan dan merupakan sumber potensial besar untuk kebahagiaan kita sendiri.

\section{Bersyukurlah}

Ketika Anda memikirkan semua hal yang harus Anda syukuri, Anda menyadari betapa terberkahinya Anda. Tanpa disadari, kita mengambil kebutuhan dasar kita begitu saja atap di atas kepalamu dan banyak makanan untuk dimakan. Dengan menghargai halhal yang sudah Anda miliki, Anda akan mulai merasa lebih bahagia dalam hidup Anda.

\section{Bagikan dengan Orang Lain}

Ketika kita berbagi pikiran kita, waktu kita, dan kemampuan kita dengan orang lain, kita merasa lebih baik untuk itu. Kehidupan yang hidup tanpa berbagi bisa menjadi sepi. 
Ketika Anda berbagi dengan orang lain, mereka akan merasa hebat terhadap Anda dan membantu Anda merasakan lebih banyak sukacita dalam hidup Anda sendiri.

\section{Senyum Lainnya}

Berlatihlah tersenyum lebih banyak dan lihat bagaimana hal itu memengaruhi Anda secara internal, serta orang-orang di sekitar Anda. Anda selalu bisa memberikan senyum. Tersenyum dapat membuat Anda lebih bahagia - bahkan jika Anda harus memaksanya, Anda akan tetap merasa lebih baik.

\section{Latihan}

Kapan terakhir kali Anda pergi ke gym atau berolahraga? Olahraga mengurangi stres dan melepaskan endorfin, juga dikenal sebagai "pelari yang tinggi". Bermain olahraga juga merupakan cara yang menyenangkan untuk berolahraga, entah itu menendang bola sepak atau lingkaran menembak.

\section{Carilah Pelatih Hidup}

Pelatih kehidupan akan membantu Anda mengevaluasi kehidupan Anda dan mengapa Anda tidak merasa bahagia di dalamnya. Mungkin Anda memegang keyakinan yang membatasi atau Anda memiliki blok emosional tanpa menyadarinya. Dengan berbicara kepada pelatih kehidupan, Anda dapat mengungkap mengapa Anda sebenarnya tidak bahagia dan apa yang dapat Anda lakukan untuk merasa lebih baik.

\section{Temukan Cara untuk Mengelola Stres}

Jangan biarkan stres merampas hak kesulungan Anda untuk bahagia. Anda berhak untuk bahagia, dan tidak akan benar membiarkan stres menghalangi Anda. Latihan seperti meditasi dapat membantu Anda mengelola stres dengan lebih baik dan merasa hebat.

\section{Makan Sehat}

Jauh lebih menantang untuk merasa benar-benar bahagia ketika Anda sakit. Tetapi ketika Anda makan dengan benar, Anda merasa lebih baik secara fisik dan mental. Dan Anda akan menghindari perasaan bersalah bahwa Anda baru saja melahap makanan sampah.

\section{Habiskan Waktu Dengan Orang Tersayang Anda}

Tidak ada pengganti untuk menghabiskan waktu berkualitas bersama orang yang Anda cintai. Kami adalah makhluk sosial, bahkan jika Anda seorang introvert atau seorang penyendiri. Orang suka menghabiskan waktu bersama teman dan keluarga mereka untuk percakapan yang baik, ikatan, dan beberapa tawa. Hidup terlalu pendek untuk hidup sepenuhnya sendirian.

\section{Buang Berpikir Negatif}

Anda sudah tahu bahwa pemikiran negatif akan membawa Anda ke bawah. Jadi bagaimana cara menghentikannya? Menjadi lebih sadar dan coba gantilah pikiran 
negatif Anda dengan pikiran positif. Habiskan lebih sedikit waktu dengan orang-orang negatif dan lebih banyak waktu bersama orang-orang yang positif.

\section{Berikan Lebih Banyak Hadiah}

Anda tidak perlu memberikan hadiah mahal; terkadang sebuah puisi, catatan singkat, atau email yang bijaksana akan mencerahkan hari orang lain, dan milik Anda. Bagikan apa yang dapat Anda berikan kepada semua orang yang menakjubkan dalam hidup Anda.

\section{Maafkan dan Lupakan}

Memendam dendam akan merugikan Anda lebih dari orang yang Anda tolak. Tanyakan kepada diri sendiri, "Apa yang diperlukan untuk saya melepaskan masa lalu?" Dan perhatikan bagaimana perasaan Anda ketika Anda melepaskan kemarahan Anda selama beberapa detik. Berfokuslah pada masa depan yang cerah dan Anda akan merasa lebih baik karenanya.

\section{Berjalanlah di Alam}

Menghabiskan waktu di alam bisa sangat menyegarkan dan memperbarui, terutama ketika Anda hidup di dunia buatan yang buatan manusia. Berjalan-jalan di hutan atau taman lokal Anda dan mendapatkan udara segar dapat memungkinkan Anda untuk menghargai keindahan alam.

\section{Jadilah Diri Sendiri}

Seperti yang dikatakan Steve Jobs, "Waktu Anda terbatas, jadi jangan sia-siakan dengan menjalani hidup orang lain." Terima siapa Anda, jadilah diri sendiri, dan Anda akan merasakan perbedaan dunia. 